\title{
Evaluation of the enrofloxacin excretion in Anatolian buffalo milk
}

\author{
Ulaş ACARÖZ ${ }^{1, a, ~} ₫$, Sinan İNCE ${ }^{2, b}$, Damla ARSLAN ACARÖZ ${ }^{3, c}$, Zeki GÜRLER $^{1, d}$, Recep KARA ${ }^{1, \mathrm{e}}$, \\ İsmail KÜÇÜKKURT ${ }^{4, f}$, Abdullah ERYAVUZ ${ }^{5, g}$
}

\begin{abstract}
${ }^{1}$ Afyon Kocatepe University, Faculty of Veterinary Medicine, Department of Food Hygiene and Technology, Afyonkarahisar; ${ }^{2}$ Afyon Kocatepe University, Faculty of Veterinary Medicine, Department of Pharmacology and Toxicology, Afyonkarahisar; ${ }^{3}$ Afyon Kocatepe University, Bayat Vocational School, Afyon; ${ }^{4}$ Afyon Kocatepe University, Faculty of Veterinary Medicine, Department of Biochemistry, Afyonkarahisar; ${ }^{5}$ Afyon Kocatepe University, Faculty of Veterinary Medicine, Department of Physiology, Afyonkarahisar, Turkey

aOORCID: 0000-0002-1533-4519; bORCID: 0000-0002-1915-9797; ' $O R C I D: 0000-0001-9230-6725$;

dORCID: 0000-0002-9037-2945; ' ORCID: 0000-0002-9257-7506; ' ORCID: 0000-0003-0198-629X; gORCID: 0000-0001-8602-2400.
\end{abstract}

\author{
Corresponding author: ulasacaroz@aku.edu.tr \\ Received date: 19.03.2020 - Accepted date: 10.10 .2020
}

\begin{abstract}
Enrofloxacin (ENR) is a broad-spectrum fluoroquinolone antibiotic widely used in both human medicine and veterinary medicine. In this study, the milk-excretion patterns of ENR and its metabolite ciprofloxacin (CIP) were determined up to the 10th milking following the intramuscular administration of ENR $(2.5 \mathrm{mg} / \mathrm{kg}$ of body weight) to lactating dairy buffaloes. The milk of each animal was collected and the concentrations of ENR and CIP were detected in milk by LC-MS/MS. The detection limits of the method were determined for ENR and CIP as $0.35 \mu \mathrm{g} / \mathrm{kg}$ and $0.12 \mu \mathrm{g} / \mathrm{kg}$, respectively. The highest total mean concentrations of ENR and its metabolite CIP was determined in the second milking after injection as $603 \mu \mathrm{g} / \mathrm{kg}$. The residue level in all buffalo milk samples was found to be lower than the maximum residue limit $(100 \mu \mathrm{g} / \mathrm{kg})$ at the fifth milking. In addition, the employed method is successfully applied to evaluate the presence of ENR and CIP residue in 50 marketed buffalo milk samples and none of the samples contained these antibiotics. Consequently, the present study provided information on the milk excretion levels of ENR and CIP in Anatolian buffalo milks by an LC-MS/MS method.
\end{abstract}

Keywords: Anatolian buffaloes, ciprofloxacin, enrofloxacin, excretion, LC-MS/MS, milk.

\section{Anadolu manda sütündeki enrofloksasin atılımının değerlendirilmesi}

Özet: Enrofloksasin (ENR), hem beşeri hekimlikte hem de veteriner hekimlikte yaygın olarak kullanılan geniş spektrumlu bir florokinolon antibiyotiktir. Bu çalışmada laktasyondaki mandalara ENR'nin (2,5 mg/kg vücut ağırlığı) intramusküler uygulamasını takiben 10. sağımına kadar ENR ve metaboliti siprofloksasinin (CIP) süt ile atılımı belirlendi. Her bir hayvanın sütü toplanarak ENR ve CIP düzeyleri LC-MS/MS ile tespit edildi. Yöntemin tespit sınırları ENR ve CIP için sırasıyla $0,35 \mu \mathrm{g} / \mathrm{kg}$ ve $0,12 \mu \mathrm{g} / \mathrm{kg}$ olarak saptandı. ENR ve metaboliti CIP'nin en yüksek toplam düzeyleri, enjeksiyondan sonraki ikinci sağımda $603 \mu \mathrm{g} / \mathrm{kg}$ olarak tespit edildi. Tüm manda sütü numunelerindeki kalıntı seviyesinin, beşinci sağımda maksimum kalıntı limitinden $(100 \mu \mathrm{g} / \mathrm{kg})$ daha düşük olduğu belirlendi. Ayrıca, kullanılan yöntem, tüketime sunulan 50 manda sütü örneğinde ENR ve CIP kalıntı varlığını değerlendirmek için başarılı bir şekilde uygulandı ve hiçbir örneğinin bu antibiyotikleri içermediği saptandı. Sonuç olarak bu çalışma, LC-MS/MS yöntemi kullanılarak Anadolu mandalarında ENR ve CIP'in süt atılım seviyeleri hakkında bilgi sağladı.

Anahtar sözcükler: Anadolu mandası, atılım, enrofloksasin, LC-MS/MS, siprofloksasin, süt.

\section{Introduction}

Milk contains several major nutrients such as fat, carbohydrates, and proteins that are essential sources to the daily diet of human. In addition, significant minerals and vitamins including magnesium, calcium, pantothenic acid, riboflavin, and vitamin $B_{12}$ are found to be in the milk content $(1,13)$. Buffalo milk provides also a very rich nutrient composition and commonly used in different types of milk products such as cream, cheese, yoghurt, and butter. In addition, this milk type is mostly produced after cow milk in the world (7).

Fluoroquinolones (FQs) exhibit a broad antibacterial spectrum by inhibiting bacterial DNA gyrase activity (15). They are frequently employed to treat many bacterial infections in human and veterinary medicine (20). However, improper or misuse of these antibiotics may 
cause antibacterial resistance in clinically important bacteria including Salmonella spp. (6), Escherichia coli (23), and Campylobacter spp. (24). Official authorities have taken precautions to continue the usage of FQs as antibiotics and to reduce their potential food-caused health risks. Since enrofloxacin (ENR) is metabolized to its major active metabolite ciprofloxacin (CIP) by deethyletion and both antibiotics are found to be in animal tissues together (28), European Union has established maximum residue limits for ENR as the sum of ENR and its metabolite CIP in milk, which is $100 \mu \mathrm{g} / \mathrm{kg}$ (8).

To analyze FQs residues in a different matrix, many methods including capillary electrophoresis (27), immunoassays (2), high-performance liquid chromatography (22), liquid chromatography-tandem mass spectrometry (LC-MS/MS) were reported. Nevertheless, LC-MS/MS is considered as the most potent confirmatory method due to its high accuracy and sensitivity (3).

The purpose of the present study is to investigate the milk excretion of ENR in the Anatolian buffalo milk by a LC-MS/MS method. Some studies have evaluated pharmacokinetics of preventatives of FQs in farm animals such as cows $(12,18)$, pigs (14), goats (25), and sheep (9). However, the persistence of ENR in the milk of Anatolian buffaloes has not been evaluated.

\section{Materials and Methods}

Materials: Enrofloxacin, Ciprofloxacin, and formic acid of analytical grade were provided by Sigma-Aldrich (St. Louis, MO, USA). Acetonitrile and water of analytical grade were obtained from Merck (Darmstadt, Germany). All other chemicals and reagents were analytical grade and purchased from commercial sources.

Five healthy female Anatolian buffaloes, weighing 400-500 kg were chosen for the present study. The experimental animals were obtained from Afyon Kocatepe University, Veterinary Faculty Research and Application Farm. In addition, the ethical approval of the study was taken from Afyon Kocatepe University Animal Experiments Local Ethics Board (49533702/98). All the animals were kept under similar conditions having standard ration and free access to water. Each experimental animal was intramuscularly given a single recommended dose of Enrofloxacin $2.5 \mathrm{mg} / \mathrm{kg}$ with a commercial product (Ekoflox 10\%, Ekomed ilaç, İstanbul, Turkey). Milk samples were collected during 5 days at the 0 (blank sample), 12, 24, 36, 48, 60, 72, 84, 96, 108, and 120 hours. The chosen milking period was determined based on the withdrawal time of ENR and CIP 4 days (8 milking) for cattle. A blank sample was taken before drug administration from each animal. Collected milk samples were directly stored at $-20^{\circ} \mathrm{C}$ for further analysis.

A total of 50 buffalo milk samples were collected from Afyonkarahisar province between August and November in 2017. Milk samples were taken by both local markets and producers. All milk samples were transported to the laboratory immediately after sampling under cold conditions and stored at $-20^{\circ} \mathrm{C}$ in a deep freezer for further analysis.

Enrofloxacin and ciprofloxacin stock solutions were prepared in methanol $(1 \mathrm{mg} / \mathrm{mL})$. To generate seven-point concentrations $(0.5,1,2,5,10,20,50 \mathrm{ng} / \mathrm{mL})$ of the calibration curve, calibration standard samples of respective antibiotics were prepared in milk by spiking with an appropriate volume serially diluted stock solution.

Methods: The buffalo milk samples were extracted as previously reported by Jank et al. (11) with some changes. $2 \mathrm{ml}$ of buffalo milk sample was given to centrifuge tube and $4 \mathrm{ml}$ of acetonitrile added to the tube. To purify milk samples, three times centrifugation was done $\left(10 \mathrm{~min}, 4000 \mathrm{rpm}\right.$ and $\left.4^{\circ} \mathrm{C}\right)$. After each centrifugation step, fat layer was discharged and the rest was re-centrifuged. The obtained supernatant was taken into a water bath $\left(\leq 45^{\circ} \mathrm{C}\right)$ and the evaporation was performed under an $\mathrm{N}_{2}$ stream. The volume of solvent was reduced to approximately $500 \mu \mathrm{l}$ under this condition. The volume was achieved to $1 \mathrm{ml}$ then transferred to HPLC vials. For LC/MS/MS analysis of milk samples, Agilent Technologies 1200 series (Waldbronn, Germany), attached with a binary high-pressure gradient pump was employed. Zorbax Eclipse XDB-C8 (150 mm × $4.6 \mathrm{~mm}$, $5 \mu \mathrm{m}$; Agilent Technologies) was used for LC separation at $45^{\circ} \mathrm{C}$. The mobile phases consisted of solvent $\mathrm{A}(20 \mathrm{mM}$ ammonium formate in $0.1 \%$ formic acid) and solvent $\mathrm{B}$ (acetonitrile). The gradient of LC separation was as follows: $0.0 \mathrm{~min}, \mathrm{~A} / \mathrm{B}(100 / 0) ; 1.0 \mathrm{~min}, \mathrm{~A} / \mathrm{B}(100 / 0) ; 3.0$ min, A/B (20/80); $9.0 \mathrm{~min}, \mathrm{~A} / \mathrm{B}(5 / 95) ; 10.00 \mathrm{~min}, \mathrm{~A} / \mathrm{B}$ (5/95), $10.10 \mathrm{~min}, \mathrm{~A} / \mathrm{B}$ (100/0). The injection volume was $20 \mu \mathrm{L}$ and the mobile phase flow rate was $0.6 \mathrm{ml} / \mathrm{min}$. Agilent 6460 LC/MS Triple Quadrupole instrument equipped with an ESI (Waldbronn, Germany) was used for mass spectrometry analysis. A nitrogen generator (Balston, Haverhill, MA, USA) was employed to produce nebulizer and drying gas $\left(350^{\circ} \mathrm{C}\right)$. All MS parameters including sheath gas flow, nebulizer gas, capillary voltage, and sheath gas temperature were $10 \mathrm{~L} / \mathrm{min}, 40$ p.s.i., 4000 $\mathrm{V}$, and $400^{\circ} \mathrm{C}$, respectively. Positive ion mode was chosen for all MS analysis. Enrofloxacin retention time was determined as 5.017. Its molecular weights, precursor ions $(\mathrm{m} / \mathrm{z})$, and product ions $(\mathrm{m} / \mathrm{z})$ were $359.9,341.8$, and 315.8, respectively. Ciprofloxacin retention time was found to be as 5.004. Its molecular weights, precursor ions $(\mathrm{m} / \mathrm{z})$, and product ions $(\mathrm{m} / \mathrm{z})$ were $332.1,314.1$, and 231.1, respectively. The validation of the method was performed by spiking raw milk samples. The quality parameters were chosen as a limit of quantification (LOQ), limit of detection (LOD), linearity range, recovery, and intra- and inter-day precisions. The residual concentrations of the milk samples were measured based on the calibration curve for which a series of standard 
solutions are prepared and calculated. The equation of calibration was established by fitting data on a line and the resulted equation is used to determine the antibiotic concentration of unknown samples. In addition, the coefficient of determination $\left(\mathrm{r}^{2}\right)$ was given to express the strength of the linear regression. The calculation of the above mentioned parameters was done using the software (Agilent MassHunter Workstation Software Version 7) of the related analytical instrument. The excretion values for ENR and CIP of five different buffaloes were given as mean \pm SD for each milking time.

LOD values of ENR or CIP were described as the lowest concentration that the analytical process can confidingly differentiate from background levels (signalto-noise ratio $\geq 3$ ) while LOQ values were defined as the lowest concentration that can be quantified (signal-tonoise ratio $\geq 10$ ).

\section{Results}

The typical chromatograms for ENR and CIP were given Figure 1. Also, the validation of the present method was determined by recovery, accuracy, precision, linearity, LOQ and LOD. LC-MS/MS was employed to quantify the level of ENR and its metabolite CIP in buffalo milk samples. Chromatographic separation of the antibiotics was also done by an LC technique in line with Chui-Shiang et al. (4). The calibration curves for ENR and CIP were presented in Figure 2 and linearity of curves exhibited appropriate the coefficient of determination $\left(r^{2}=0.997\right.$ and $\left.r^{2}=0.998\right)$ in the range from 0.5 to $50 \mu \mathrm{g} / \mathrm{kg}$. Also, the method possessed high sensitivity and LOD and LOQ values were given in Table 1 . The overall precision of the method was expressed by relative standard deviation (RSD\%) which was lower than 6.9\%. Intra-day and inter-day recoveries were used to express the accuracy of the method at three different levels of $45,90,135 \mu \mathrm{g} / \mathrm{kg}$. Intra-day and inter-day recoveries and RSD values were given for ENR and CIP in Table 2 and Table 3, respectively. Some parameters of the developed instrumental methods for the determination of ENR and CIP residues in milk were given in Table 4.

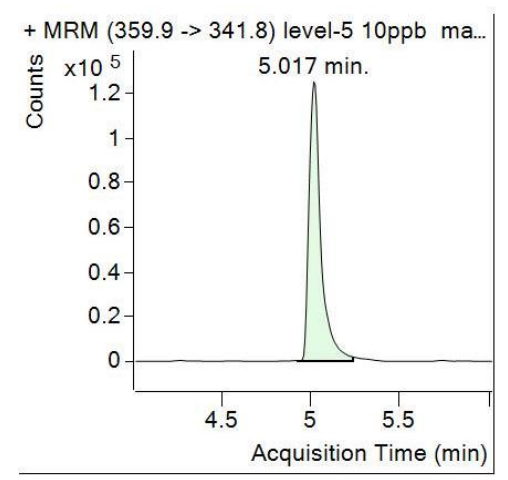

A

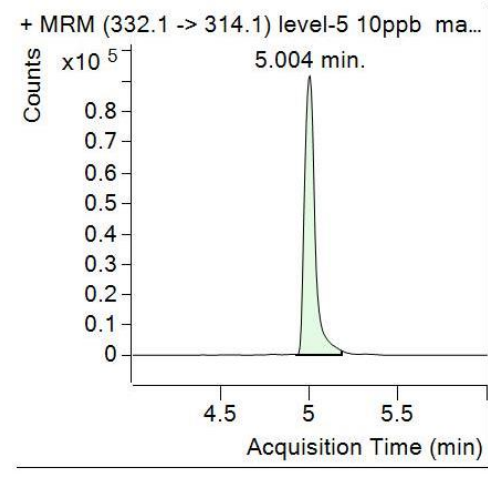

B

Figure 1. Chromatograms of enrofloxacin (A) and ciprofloxacin (B) standards.

A
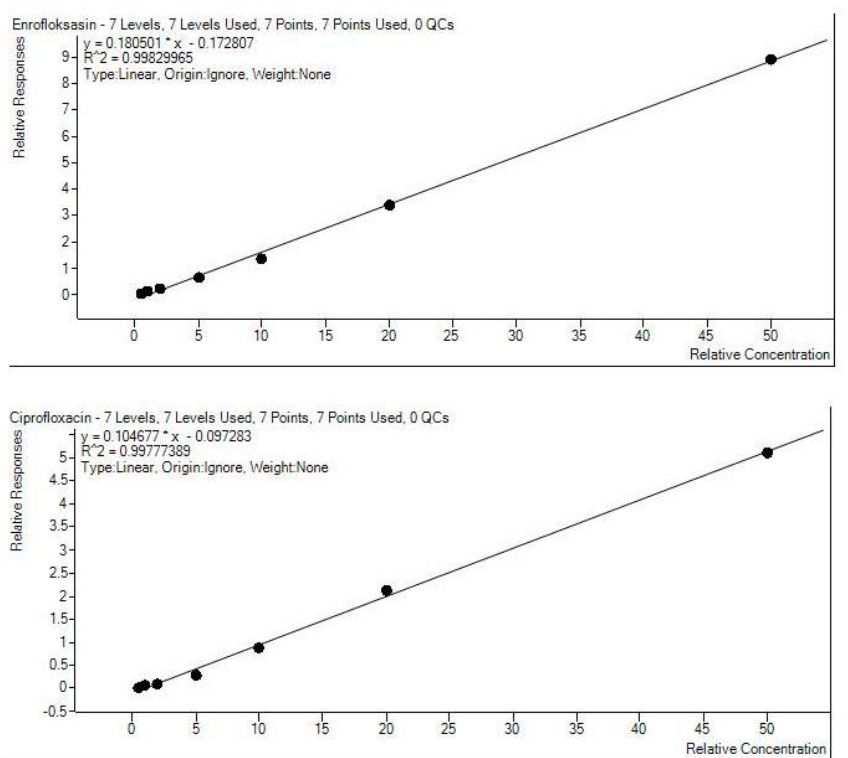

Figure 2. Calibration curves for enrofloxacin (A) and ciprofloxacin (B). 
Table 1. Analytical parameters of enrofloxacin and ciprofloxacin in buffalo milk samples.

\begin{tabular}{|c|c|c|c|c|c|c|}
\hline Antibiotic & LOD $(\mu \mathrm{g} / \mathrm{kg})$ & LOQ $(\mu \mathrm{g} / \mathrm{kg})$ & $\begin{array}{c}\text { Coefficient of } \\
\text { determination }\left(r^{2}\right)\end{array}$ & Data point & $\begin{array}{c}\text { Linear range } \\
(\mu \mathrm{g} / \mathrm{kg})\end{array}$ & RT (min) \\
\hline Enrofloxacin & 0.35 & 1.16 & 0.998 & 7 & $0.5-50$ & 5.017 \\
\hline Ciprofloxacin & 0.12 & 0.40 & 0.997 & 7 & $0.5-50$ & 5.004 \\
\hline
\end{tabular}

Table 2. Intra- and inter-day precisions for enrofloxacin in buffalo milk samples.

\begin{tabular}{lcccc}
\hline & \multicolumn{2}{c}{ Intra-day assays $(\mathbf{n = 9})$} & \multicolumn{2}{c}{ Inter-day assays $(\mathbf{n}=\mathbf{9})$} \\
\hline Spiked $(\mathbf{p p b})$ & $\begin{array}{c}\text { Percentage } \\
\text { Recovery } \pm \mathbf{C V}\end{array}$ & $\begin{array}{c}\text { RSD } \\
(\boldsymbol{\%})\end{array}$ & $\begin{array}{c}\text { Percentage } \\
\text { Recovery } \pm \mathbf{C V}\end{array}$ & $\begin{array}{c}\text { RSD } \\
(\boldsymbol{\%})\end{array}$ \\
\hline 45 & $84.73 \pm 4.43$ & 5.23 & $84.42 \pm 4.60$ & 5.58 \\
90 & $80.52 \pm 3.44$ & 4.27 & $75.69 \pm 3.45$ & 4.56 \\
135 & $93.28 \pm 3.34$ & 3.58 & $79.02 \pm 5.16$ & 6.53 \\
\hline
\end{tabular}

Table 3. Intra- and inter-day precisions for ciprofloxacin in buffalo milk samples.

\begin{tabular}{ccccc}
\hline & \multicolumn{2}{c}{ Intra-day assays $(\mathbf{n = 9})$} & \multicolumn{2}{c}{ Inter-day assays $(\mathbf{n}=\mathbf{9})$} \\
\hline Spiked $(\mathbf{p p b})$ & $\begin{array}{c}\text { Percentage } \\
\text { recovery } \pm \mathbf{C V}\end{array}$ & $\begin{array}{c}\text { RSD } \\
(\boldsymbol{\%})\end{array}$ & $\begin{array}{c}\text { Percentage } \\
\text { recovery } \pm \mathbf{C V}\end{array}$ & $\begin{array}{c}\text { RSD } \\
(\boldsymbol{\%})\end{array}$ \\
\hline 45 & $84.41 \pm 3.90$ & 4.62 & $83.88 \pm 5.09$ & 6.07 \\
90 & $76.07 \pm 3.15$ & 4.14 & $74.99 \pm 3.49$ & 4.65 \\
135 & $83.00 \pm 3.01$ & 3.63 & $75.57 \pm 5.22$ & 6.90 \\
\hline
\end{tabular}

Table 4. Selective methods for the quantification of enrofloxacin and ciprofloxacin in milk.

\begin{tabular}{ccccccc}
\hline Method Type & Analyte & Matrix & $\begin{array}{c}\text { LOD } \\
\boldsymbol{\mu g} / \mathbf{k g}\end{array}$ & $\begin{array}{c}\text { LOQ } \\
\boldsymbol{\mu g} / \mathbf{k g}\end{array}$ & $\begin{array}{c}\text { Recovery } \\
(\boldsymbol{\%})\end{array}$ & Reference \\
\hline LC-MS & ENR & Buffalo Milk & 0.35 & 1.16 & $75-93$ & Current Study \\
& CIP & & 0.12 & 0.40 & $74-84$ & 26 \\
LC-MS & ENR & Bovine Milk & 0.3 & 1 & $77-84$ & 5 \\
HPLC-DAD & ENR & Goat Milk & 15 & 20 & $81-86$ & 10 \\
& CIP & & 15 & 20 & $85-89$ & \\
HPLC-FAD & ENR & Bovine Milk & NA & 2 & $91-107$ & 16 \\
& CIP & & NA & 2 & $95-101$ & \\
& ENR & Bovine Milk & 1.37 & 4.56 & $93-99$ & $89-97$ \\
\end{tabular}

NA: Not available.

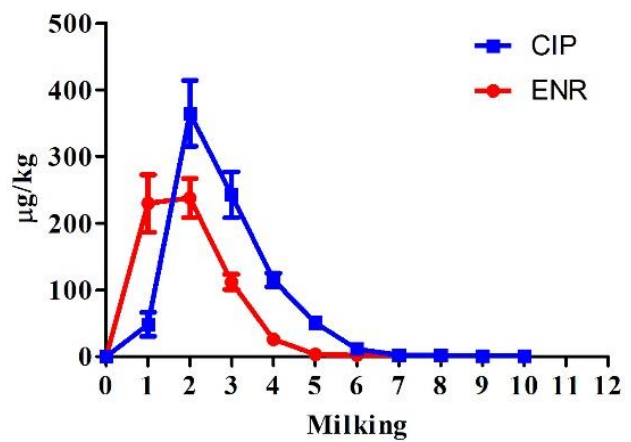

A

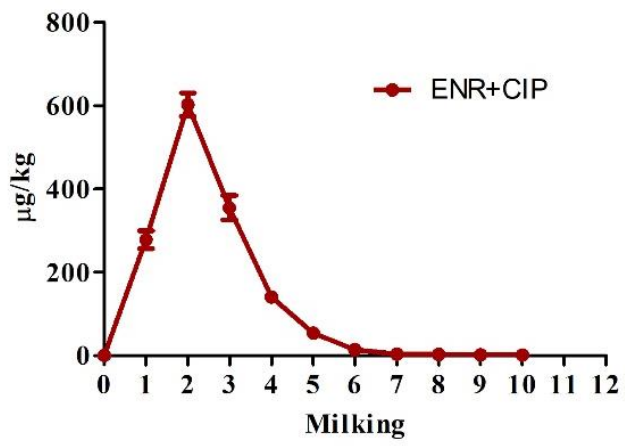

B

Figure 3. Excretion levels of enrofloxacin and its metabolite ciprofloxacin in milk of buffaloes. Separate excretion kinetics for each antibiotic (A), total excretion kinetics (B) ${ }^{1}$.

${ }^{1}$ European Union has established maximum residue limits for ENR as the sum of ENR and its metabolite CIP in milk which is 100 $\mu \mathrm{g} / \mathrm{kg}$. 
In this study, the highest concentrations of ENR and CIP were determined at the second milking with a mean concentration of $238.03 \pm 29.4$ and $365.21 \pm 49.44 \mu \mathrm{g} / \mathrm{kg}$, respectively (Figure 3). Also, the total sum of ENR and its metabolite CIP in milk was decreased after the second milking consequently and their total concentration was found to be lower than the maximum residue limit (100 $\mu \mathrm{g} / \mathrm{kg}$ ) at fifth milking. The mean concentration of CIP in milk was measured at 10 milking post-treatment $1.63 \pm 0.12 \mu \mathrm{g} / \mathrm{kg}$ while the concentration of ENR was lower than the related LOD.

In addition, 50 buffalo milk samples marketed in Afyonkarahisar were tested regarding ENR and CIP residues and results of the analysis showed that none of the milk samples contained ENR and/or CIP.

\section{Discussion and Conclusion}

Fluoroquinolone antibiotics are commonly employed in human and veterinary medicine to treat bacterial infections based on their broad antibacterial activity (2). The LOD values of the present study for ENR and CIP were determined as 0.35 and $0.12 \mu \mathrm{g} / \mathrm{kg}$, respectively while LOQ values were determined as 1.16 and $0.40 \mu \mathrm{g} / \mathrm{kg}$ for ENR and CIP, respectively. In a similar LC-MS method established for ENR analysis, LOD and LOQ values were reported as 0.3 and $1 \mu \mathrm{g} / \mathrm{kg}$, respectively (26). Also, higher LOD (15 $\mu \mathrm{g} / \mathrm{kg})$ and LOQ $(20 \mu \mathrm{g} / \mathrm{kg})$ values were reported for ENR and CIP analysis by using HPLC-DAD method in goat milk (5). Recovery values of the present study ranged from $75 \%$ to $93 \%$ for ENR whereas these values were determined between $74 \%$ and $84 \%$ for CIP. These values are compatible with the Cinquina et al. (5) and Tian (26). However, they are lower than the values reported by Idowu and Peggins (10) and Lv et al. (16).

The present experimental research followed the passage of ENR and its metabolite CIP into buffalo milk and determined their milk excretion kinetics using LCMS/MS. ENR and CIP were determined in milk from 0 to 10 milkings following intramuscular injection of ENR to dairy buffaloes. The highest concentrations of ENR which is described as a total sum of ENR and its metabolite CIP by EU commission regulation (8) were found to be at the second milking $(603.24 \pm 27.97 \mu \mathrm{g} / \mathrm{kg})$ and residue level in milk was found to be lower than the maximum residue limit of $100 \mu \mathrm{g} / \mathrm{kg}$ (8) at fifth milking. The persistence of ENR and CIP in the milk of livestock animals was reported by some previous studies. In one of these studies, Mahmood et al. (17) determined the persistence of fluoroquinolone antibiotics in cow milk. For that purpose, lactating animals were intramuscularly injected with Norfloxacin (NOR), ENR, CIP at the dose of 5, 2.5, and 5 $\mathrm{mg} / \mathrm{kg}$, respectively. Spectrophotometrically evaluation of milk samples showed that NOR was present in milk samples until the $5^{\text {th }}$ days while ENR was washed out in 6 days. However, CIP was longer persistent in milk up to 8 days. In the present study, ENR was washed out at the 5 days. This may be attributed to employed method and/or animal species. In another study conducted by Kaartinen et al., (12), Five Ayrshcre cows were given enrofloxacin at the dose of $5 \mathrm{mg} / \mathrm{kg}$ body weight in three different ways including intravenous, intramuscular and subcutaneous and residue analysis of ENR and CIP was done with HPLC. The ENR found to be bounded to serum proteins at ratio of $36-45 \%$. Approximately, $0.2 \%$ of the total ENR dose was detected in milk for the first $24 \mathrm{~h}$ and the transferred amount has not been affected by the administration route. The concentration of ENR in milk was determined in line with that in serum, whereas CIP was detected more concentrated in milk. Additionally, following the intravenous injection, the peak milk concentration of ENR and CIP was more distinctive comparing to intramuscular and subcutaneous routes. Also, intramuscular injection of ENR was resulted in similar residue level in milk in the present study. Haritova et al. (9) evaluated pharmacokinetics of enrofloxacin in lactating sheep by administrating ENR intravenously and intramuscularly at a dose rate of $2.5 \mathrm{mg} / \mathrm{kg}$ body weight. Their results showed that $24 \mathrm{~h}$ after the intravenous treatment of ENR, this antibiotic was found to be 10 times higher in the milk than the serum. Higher levels of ENR which is lipophilic drug in milk may be due to the low degree of binding of the ENR to serum proteins (29). After intramuscular treatment of ENR, its milk concentration was also more concentrated than those in the serum and these results indicate that the route of administration does not play a role in the good penetration of ENR into milk and its milk concentrations. In addition, the concentration of ENR was reached to peak level at the 24 hours after the application. Similarly, in this study the peak of ENR concentration was observed after 24 hours. The present study investigated for the first time, the persistence of ENR and CIP in the milk of Anatolian buffalos and results of the study regarding the milk concentration of ENR and CIP are comparable with the above-mentioned studies.

Also, a mini survey was conducted to screen the presence of ENR and CIP buffalo milk samples $(n=50)$ marketed in Afyonkarahisar and results of the analysis showed that none of the milk samples contained ENR and/or CIP. Similarly, Nirala et al. (21) screened a total of 250 milk samples in India and reported that none of the samples were positive for ENR and CIP. In another study, 234 randomly milk samples from each of bulk tank, market milk, collecting centers, and UHT milk samples were tested for determination of the quinolones residues. Results revealed that quinolones were not detected in 
collecting centers and market milk samples whereas was found to be in one sample bulk tank milk samples (19).

In conclusion, the present study reports here the milk excretion of ENR and its metabolite CIP for the Anatolian buffaloes by an accurate, precise, and reliable, LCMS/MS method combined with easy sample preparation step. The LOD and LOQ values of this method are able to detect these antibiotics within the established MRL in milk. This developed method could be used for the analysis of ENR and CIP in buffalo milk. Also, the present study provided new information about the withdrawal period of ENR and its metabolite CIP in buffalo milk. This result showed that withdrawal period of ENR in buffalo milk is compatible with the withdrawal time established for cattle by the EU. In addition, real milk samples were analyzed and found to be safe regarding ENR residue risk in Afyonkarahisar Province of Turkey.

\section{Financial Support}

This study was financially supported by the Afyon Kocatepe University Scientific Research Council, Afyonkarahisar, Turkey (Project no: 17.VF.08).

\section{Ethical Statement}

This study was approved by Afyon Kocatepe University Animal Experiments Local Ethics Board (49533702/98).

\section{Conflict of interest}

The authors declared that there is no conflict of interest.

\section{References}

1. Acaroz U, Arslan-Acaroz D, Ince S (2019): A Wide Perspective on Nutrients in Beverages. 1-39. In: Grumezescu AM and Holban AM (Ed) Nutrients in Beverages. Academic Press.

2. Acaroz U, Dietrich R, Knauer M, et al (2019): Development of a Generic Enzyme-Immunoassay for the Detection of Fluoro(quinolone)-Residues in Foodstuffs Based on a Highly Sensitive Monoclonal Antibody. Food Anal Methods, 13, 780-792.

3. Acaroz U, Ince S, Arslan-Acaroz D, et al (2020): Determination of kanamycin residue in anatolian buffalo milk by LC-MS/MS. Kafkas Univ Vet Fak Derg, 26, 97-102.

4. Chui-Shiang C, Wei-Hsien W, Chin-En T (2010): Simultaneous Determination of 18 Quinolone Residues in Marine and Livestock Products by Liquid Chromatography/ Tandem Mass Spectrometry. J Food Drug Anal, 18, 87-97.

5. Cinquina AL, Roberti P, Giannetti L, et al (2003): Determination of enrofloxacin and its metabolite ciprofloxacin in goat milk by high-performance liquid chromatography with diode-array detection: Optimization and validation. J Chromatogr A, 987, 221-226.
6. Cuypers WL, Jacobs J, Wong V, et al (2018): Fluoroquinolone resistance in Salmonella: Insights by wholegenome sequencing. Microb Genomics, 4, e000195.

7. Du C, Deng T, Zhou Y, et al (2019): Systematic analyses for candidate genes of milk production traits in water buffalo (Bubalus Bubalis). Anim Genet, 50, 207-216.

8. EU Commission Regulation (2019): Pharmacologically active substances and their classification regarding maximum residue limits in foodstuffs of animal origin. Available at https://ec.europa.eu/health/sites/health/files/ files/eudralex/vol-5/reg_2010_37/reg_2010_37_en.pdf. (Accessed January 20, 2020).

9. Haritova A, Lashev L, Pashov D (2003): Pharmacokinetics of enrofloxacin in lactating sheep. Res Vet Sci, 74, 241-245.

10. Idowu OR, Peggins JO (2004): Simple, rapid determination of enrofloxacin and ciprofloxacin in bovine milk and plasma by high-performance liquid chromatography with fluorescence detection. J Pharm Biomed Anal, 35, 143-153.

11. Jank L, Martins MT, Arsand JB, et al (2015): Highthroughput method for the determination of residues of $\beta$ lactam antibiotics in bovine milk by LC-MS/MS. Food Addit Contam - Part A Chem Anal Control Expo Risk Assess, 32, 1992-2001.

12. Kaartinen L, Salonen M, Älli L, et al (1995): Pharmacokinetics of enrofloxacin after single intravenous, intramuscular and subcutaneous injections in lactating cows. J Vet Pharmacol Ther, 18, 357-362.

13. Kara R, Acaroz U, Gurler Z, et al (2018): Manda Sütlerinde ICP-MS ile Metal ve A $\breve{g}$ ır Metal Seviyelerinin Belirlenmesi. Kocatepe Vet J, 11, 1-4.

14. Lei Z, Liu Q, Yang B, et al (2017): Clinical efficacy and residue depletion of $10 \%$ enrofloxacin enteric-coated granules in pigs. Front Pharmacol, 8, 1-11.

15. Lizondo M, Pons M, Gallardo $M$, et al (1997): Physicochemical properties of enrofloxacin. J Pharm Biomed Anal, 15, 1845-1849.

16. Lv YK, L Yang, XH Liu, et al (2013): Preparation and evaluation of a novel molecularly imprinted hybrid composite monolithic column for on-line solid-phase extraction coupled with HPLC to detect trace fluoroquinolone residues in milk. Anal Methods, 5, 1848 1855.

17. Mahmood T, Abbas M, Ilyas S, et al (2016): Quantification of fluoroquinolone (enrofloxacin, norfloxacin and ciprofloxacin) residues in cow milk. IJCBS, 10, $10-15$

18. Malbe M, Salonen M, Fang W, et al (1996): Disposition of enrofloxacin (Baytril) into the udder after intravenous and intra-arterial injections into dairy cows. J Vet Med A, 43, 377-386.

19. Mohammed HA, Abdou AM, Eid AM, et al (2016): Rapid tests for detection of enrofloxacin residues in liquid milk. Benha Vet Med J, 30, 97-103.

20. Naeem A, Badshah SL, Muska M, et al (2016): The current case of quinolones: Synthetic approaches and antibacterial activity. Molecules, 21, 268. 
21. Nirala RK, Anjana K, Mandal KG, et al (2017): Persistence of antibiotic residue in milk under region of Bihar, India. Int J Curr Microbiol App Sci, 6, 2296-2299.

22. Piñero MY, Fuenmayor M, Arce L, et al (2013): A simple sample treatment for the determination of enrofloxacin and ciprofloxacin in raw goat milk. Microchem J, 110, 533-537.

23. Rath S, Padhy RN (2015): Prevalence of fluoroquinolone resistance in Escherichia coli in an Indian teaching hospital and adjoining communities. J Taibah Univ Med Sci, 10, 504-508.

24. Sierra-Arguello YM, Furian TQ, Perdoncini G, et al (2018): Fluoroquinolone resistance in Campylobacter jejuni and Campylobacter coli from poultry and human samples assessed by PCR-restriction fragment length polymorphism assay. PLoS One, 13, 1-9.
25. Talpade J (2018): pharmacokinetic study of single dose intravenous administration of enrofloxacin in Barbari goats. J Anim Res, 8, 609-611.

26. Tian H (2011): Determination of chloramphenicol, enrofloxacin and 29pesticides residues in bovine milk by liquid chromatography-tandem mass spectrometry. Chemosphere, 83, 349-355.

27. Tian Z, Gao JJ, Qin W (2018): Determination of fluoroquinolones in milk by ionic liquid-mediated two phase extraction followed by capillary electrophoresis analysis. Madridge J Anal Sci Instrum, 3, 62-67.

28. Trouchon T, Lefebvre S (2016): A review of enrofloxacin for veterinary use. Open J Vet Med, 6, 40-58.

29. Ziv G (1994): Pharmacokinetics of Antibacterial Fluoroquinolones in Small and Large Animal Practice. 194196. In: Proceedings of the 6th Congress of EAVPT Congress, Edinburgh. 